\title{
THE EFFECTIVENESS OF ORAL SUCROSE ON PAIN DURING INVASIVE PROCEDURES IN PREMATURE INFANTS: SCOPING REVIEW
}

\author{
Kamilah Hayatun Nufus ${ }^{1^{*}}$, Adinda Salsabilah ${ }^{2}$, Nurul Aeni ${ }^{3}$, Zakiyyah Arief Atshillah ${ }^{4}$, Casman $^{5}$ \\ 1. Diploma of Nursing Program, STIKes RS Husada, Jakarta-Indonesia \\ 2. Diploma of Nursing Program, STIKes RS Husada, Jakarta-Indonesia \\ 3. Diploma of Nursing Program, STIKes RS Husada, Jakarta-Indonesia \\ 4. Diploma of Nursing Program, STIKes RS Husada, Jakarta-Indonesia \\ 5. Diploma of Nursing Program, STIKes RS Husada, Jakarta-Indonesia
}

*Correspondence: Kamilah Hayatun Nufus | STIKes RS Husada | kamilahhayatunnufus35@gmail.com

\begin{abstract}
Introduction: Nowadays premature births continue to be common, it caused the infant necessitating treatment. Invasive procedures, such as the placement of an peripheral intravenous catheters or the drawing of blood, should be carried out while the baby is being cared for. Some intervention needed, sucrose is one approach to make invasive procedure less painful. This study aims to determine the effectiveness of oral sucrose in reducing the pain of invasive procedures in premature infants.

Method: This study is a scoping review, and 11 articles were selected from Proquest, ScienceDirect, Willy Online, PubMed, and EBSCO (CINAHL) databases.

Results: In eight of the articles, giving oral sucrose two minutes before the invasive procedure was effective in reducing pain, while sucrose was not effective in reducing pain in infants in the other three of the articles, during or after procedures.

Conclusion: According to these studies, giving oral sucrose to premature infant before invasive procedure is significant reducing the pain during invasive procedure.
\end{abstract}

Keywords: Oral sucrose, Pain of invasive procedure, Premature infant.

Received November 5, 2021; Accepted December 30, 2021

\section{INTRODUCTION}

In 2018, there were $28 \%$ of babies born with a birth weight record (WHO, 2019). Indonesia had a baby birth rate of 4,792,117 in 2019 (KPPA \& BPS, 2019). In 2018, 56.6\% of babies were born, and $6.2 \%$ of them were born with low birth weight/LBW (Kemenkes RI, 2018). The prevalence of LBW fell by $1 \%$ in 2015, from 14.7 percent in 2014 to 14.6 percent in 2015 (WHO, 2019). Premature babies are LBW in 2/3 of the cases (Rustina, 2015). Premature births are high in 184 countries, ranging from 5-18\% (WHO, 2018).

LBW experienced more than ten procedures that caused pain and discomfort during intensive care (Asadi-Noghabi et al., 2014). Data from the perinatology room at K.R.M.T Wongsonegoro Hospital Semarang was obtained on neonates from August 2019 to July 2020; there were 879 babies and 459 (52\%) infusions were installed (Hastuti et al., 2021) Painful procedures involving the collection of venous blood are the most painful for 55-86 percent of patients (Beheshtipoor et al., 2014). The frequent insertion of IV catheters undoubtedly contributes to increased patient morbidity, increased treatment costs, and stress for families and nurses who perform treatment (Widayati et al., 1996)

Atraumatic care can be provided to children as the most important intervention in child care to ensure optimal growth and development while they are in the hospital. The role of the nurse is to provide such atraumatic care, one of which is to prevent trauma and reduce pain, where trauma and pain are most often caused by painful procedures such as injections (Wulandari, 2011). Non-pharmacological measures that are effective at reducing pain and minimizing side effects are used as an option. There are several nonpharmacological methods for reducing pain in infants, such as skin-to-skin or kangaroo mother care, music therapy, touch therapy, or massage (Liaw et al., 2013). Furthermore, sucrose administration can be one of the non-pharmacological measures used to reduce pain in infants during invasive procedures (Hatfield et al., 2008). Based on the aforementioned phenomena, the purpose of this study is to determine the efficacy of oral sucrose administration in reducing pain during invasive procedures (needling) in premature infants. 


\section{METHOD}

This is a scoping review article. Use a combination of keywords to search articles in several databases, including ProQuest, ScienceDiretWiley Online, Pubmed, and Ebsco (CINAHL), including: oral sucrose, su crose, pain, newborn, infant, neonatal, and neonate.

Search for articles that meet the following inclusion criteria: (1) English-language articles, (2) articles containing information about the oral administration of sucrose to infants to relieve pain, and (3) articles containing information about the administration of sucrose to infants to relieve pain. RCTs are used in three (3) of the articles. (4) Articles published between 2017 and 2021 are chosen for limitation. Articles that did not cover invasive needle stick procedures were not considered (eg urinary catheter insertion, NGT, etc). There were 11 articles chosen based on PRISMA (see Figure 1).

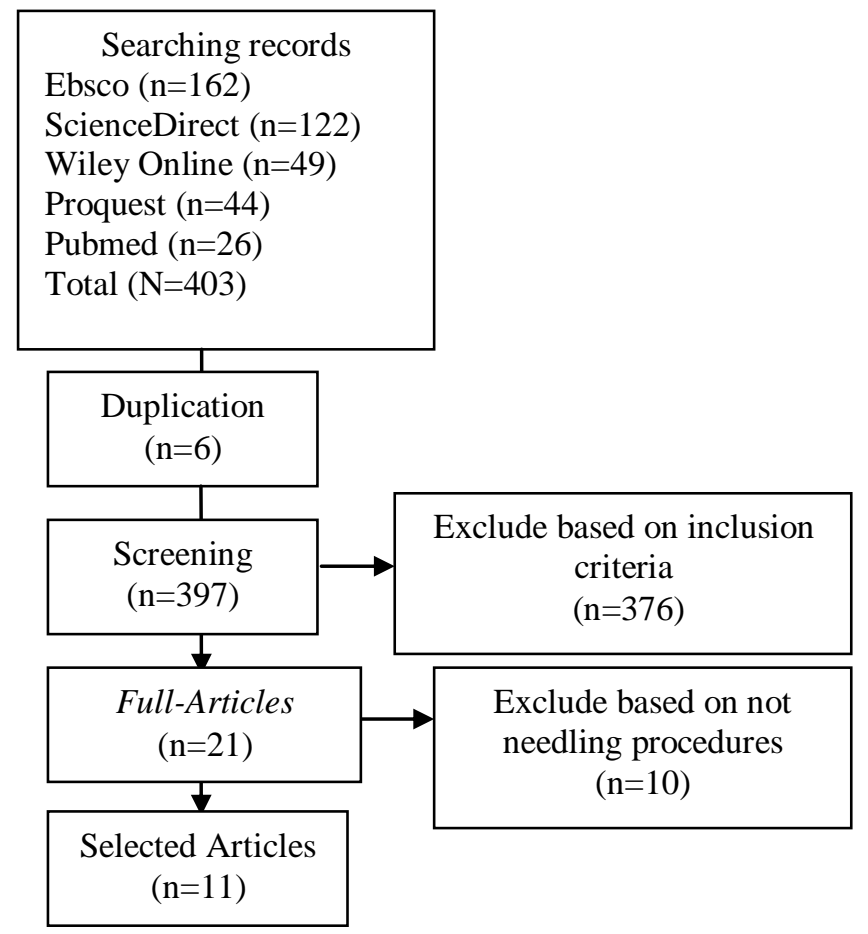

Figure 1. PRISMA diagram

\section{RESULTS}

Table 1. Intervention of oral sucrose in premature infant

\begin{tabular}{|c|c|}
\hline $\begin{array}{l}\text { (Author) } \\
\text { Country }\end{array}$ & Summary of Each Articles \\
\hline $\begin{array}{l}\text { (Cook et al., } \\
\text { 2017) } \\
\text { Amerika Serikat }\end{array}$ & $\begin{array}{l}\text { Intervention: oral sucrose } 24 \%(5 \mathrm{ml}) \text { on intervention group, and placebo ( } 5 \mathrm{ml} \text { water) in } \\
\text { control group. Intervention given } 2 \text { minutes before procedure. Both groups of children were } \\
\text { swaddled and given pacifiers during the infusion. } \\
\text { Sample Age: } 46 \text { infants in the NICU were at least } 27 \text { weeks gestation, with } 22 \text { infants in the } \\
\text { intervention group and } 24 \text { infants in the control group. However, only } 20 \text { infants from each } \\
\text { group were included in the analysis. } \\
\text { Pain Measurement : used Premature Infant Pain Profile (PIPP) before insertion to } 5 \\
\text { minutes after procedures. } \\
\text { Result: Infusions were completed in less than } 5 \text { minutes by } 78 \% \text { of infants, with the } \\
\text { remainder taking less than } 5 \text { minutes. There was no difference in pain scores between the } \\
\text { sucrose and placebo groups (p=0.129). The mean stabbing pain in the sucrose group was } \\
6.5 \text {, while it was } 8 \text { in the placebo group. } \\
\text { Conclusion: In } 40 \text { neonates, a } 24 \% \text { oral sucrose solution did not significantly reduce } \\
\text { infusion-related pain when compared to a placebo. }\end{array}$ \\
\hline (Gouin et al., & Intervention: The sucrose group ( 38 infants) received $2 \mathrm{~mL}$ of an 88 percent sucrose \\
\hline
\end{tabular}




\begin{tabular}{ll}
\hline \multicolumn{1}{c}{$\begin{array}{c}\text { (Author) } \\
\text { Country }\end{array}$} & \multicolumn{1}{c}{ Summary of Each Articles } \\
\hline Kanada & $\begin{array}{l}\text { solution (BP Syrup), while the placebo group (38 infants) received 2 mL of a placebo } \\
\text { solution (sterile water). The solution was given to both groups 2 minutes before the } \\
\text { venipuncture. }\end{array}$ \\
& Sample Age : 76 premature infant, age of 28 days -3 months \\
& Pain Measurement: used Face, Legs, Activity, Cry and Consolability Pain Scale \\
& (FLACC), and Neonatal Infant Pain Scale (NIPS) \\
& Result: The mean difference in FLACC pain scores between 1 minute after venipuncture in \\
& the sucrose group was 2.846.64 vs. 2.71 6.62 in the placebo group (p = 0.98). There was no \\
& statistically significant difference in NIPS scores between the two groups after 1 minute: \\
& 2,326.47 (sucrose) vs. 1.63.49 (placebo) (p = 0.60). \\
& Conclusion: The administration of an oral sweetened solution had no statistically \\
& significant effect on pain scores as measured by the FLACC and NIPS scales.
\end{tabular}

(Shah et al., Intervention: The first group received 24 percent sucrose in the amount of $5 \mathrm{~mL} 2 \mathrm{minutes}$ 2017) Australia before blood collection, the second group received a combination intervention (music and sucrose), and the third group received music therapy from 20 minutes before the injection until 7 minutes after the injection.

Sample Age : 35 infant with age of gestation 35 weeks.

Pain Measurement: used Premature Infant Pain Profile-Revised scale (PIPP-R).

Result: The music group had a median pain score of 4, the sucrose group had a score of 3, and the combination group had a score of 1 . The three interventions significantly reduced pain in infants during blood sampling $(\mathrm{p}=0.001)$.

Conclusion: Music therapy, sucrose, and a combination are effective for relieving pain in neonates during blood collection procedures. The most effective method, however, is to use a combination of sucrose and music therapy.

(Collados- Intervention: The first group was given breast milk, while the second group was given Gomez et al., $\quad$ sucrose $(0.05-0.5 \mathrm{~mL}$ sucrose 24 percent $)$. The intervention was given about two minutes 2018) Spanyol

(Gao et al., 2018) China

(Kristoffersen et al., 2018) Norwegia and Afrika Selatan before the procedure.

Sample Age: premature infant with age of gestation less than 37 weeks

Pain Measurement: used PIPP

Result: The difference between the two groups was not statistically significant. With breast milk, the PIPP score was seven (4-9) and with sucrose, it was six $(4-8.25)(\mathrm{p}=0.28)$. The 11 infants born under 28 weeks had higher mean scores for breast milk of nine (9-14) and sucrose of four $(4-7)(\mathrm{p}=0.009)$.

Conclusion : In the majority of preterm neonates, EBM and 24 percent sucrose have the same analgesic effect during venipuncture, but sucrose works better in very premature infants.

Intervention : 22 infants received a pacifier 2 minutes before the injection, 21 infants received 20 percent sucrose at a dose of $0.2 \mathrm{ml} / \mathrm{kg}, 22$ infants received a combination intervention, and 21 infants served as the control group.

Sample Age : premature infant with age of gestation less than 37 weeks

Pain Measurement: used PIPP from recording video

Result: The combination intervention (pacifier and sucrose) significantly reduced pain during needle insertion in infants $(\mathrm{p}=0.001)$, whereas other pain-reduction methods were not proven to be effective.

Conclusion: Sucrose alone is ineffective in reducing pain during blood collection in infants.

Intervention: The first group of 23 infants received $0.2 \mathrm{~mL}$ of sucrose, while the second group of 30 infants received $0.5 \mathrm{~mL}$ of sucrose. Sucrose was given two minutes before the needle was inserted. South Africa uses 25\% sucrose, while Norway uses 24\% sucrose. Sample Age : Infants weighing more than 1,000 grams at birth and born at least 18 weeks gestation, according to USG.

Pain Measurement: used PIPP-R

Result: The mean pain score during stabbing was significantly lower with $0.5 \mathrm{~mL}$ of 


\begin{tabular}{ll}
\hline $\begin{array}{c}\text { (Author) } \\
\text { Country }\end{array}$ & \multicolumn{1}{c}{ Summary of Each Articles } \\
\hline & $\begin{array}{l}\text { sucrose compared to } 0.2 \mathrm{~mL}(5.3 \text { versus } 6.8, \mathrm{p}=0.008) . \\
\text { Conclusion: In infants, sucrose at a dose of } 0.5 \mathrm{~mL} \text { is more effective than sucrose at a dose } \\
\text { of } 0.2 \mathrm{~mL} \text { in reducing pain during venipuncture. }\end{array}$
\end{tabular}

(Shukla et al., 2018) Amerika Serikat

(Passariello et al., 2019)

Italia

(Fitri et al., 2020) Indonesia

(Barandouzi et al., 2020) Iran
Intervention: The first group received kangaroo method treatment (PMK) for up to 50 babies, while the second group received sucrose (50 babies). FMD was given at least 10 minutes before the procedure, and $0.2 \mathrm{~mL}$ sucrose was given 2 minutes before it.

Sample Age : One hundred premature neonates (29 to 36 weeks gestation) in the NICU will have their blood drawn.

Pain Measurement:. The PIPP instrument is used to measure pain. Using recorded videos, pain scores were taken 30 seconds after the procedure. The video was recorded from 5 minutes before the stabbing to 1 minute after the stabbing.

Result: The FMD group had a lower total PIPP score than the Sucrose group, but there was no statistically significant difference [7.74 (2.43) vs. 8.1 (2.82), $\mathrm{p}=0.50]$.

Conclusion: SSC and sucrose have comparable pain-reduction effects in premature neonates during needle insertion.

Intervention: The intervention group of 25 infants received 24 percent sucrose in a dose of $1.5 \mathrm{ml}$ if the baby weighed more than 3,000 grams and $1 \mathrm{ml}$ if the baby weighed less than 3,000 grams, while the control group received a placebo (water).

Sample Age : premature infant

Pain Measurement: used skin conductance algesimeter (SCA) pain monitor index. Result: In the placebo group, $8(32 \%)$ had capillary blood withdrawal and $17(68 \%)$ had arterial blood withdrawal. In the sucrose group, $10 \%$ (32\%) underwent capillary withdrawal and $21 \%(68 \%)$ underwent arterial withdrawal. The SCA results revealed that peaks per second were lower in the sucrose group compared to the placebo group during all procedures, and this difference was statistically significant $(\mathrm{p}=0.001)$. Peaks per second were lower in the sucrose group three minutes after the procedure than in the placebo group. Conclusion: This study confirms that sucrose administration is effective for the prevention and treatment of neonatal pain during blood collection.

Intervention: Sensory saturation and sucrose were given to the first group (36 babies). The intervention was given 30 seconds before blood collection, the second group was given sensory saturation and breast milk (36 babies), and the third group was given only 24 percent sucrose (36 babies) 30 seconds before and during blood sampling. The nurse begins sensory saturation by talking to the baby, looking into the baby's eyes, gently massaging the baby's cheeks and other facial areas, and then feeding the baby breast milk or sucrose until the baby sucks rhythmically.

Sample Age : 108 infants receiving breast milk from their mothers who were at least 48 hours postpartum, had a gestational age of 32 weeks, and had an Apgar score of at least 8 at 5 minutes. While neonates receiving analgesics and sedatives are not permitted.

Pain Measurement: used Prematur Infant Pain Profile-Revised (PIPP-R).

Result: Sucrose SS and breast milk SS outperformed S24 percent $(p=0.001)$. The difference between SSB and SSS was not statistically significant $(\mathrm{p}=0.669)$.

Conclusion: Multisensory stimulation is more effective than unimodal analgesia in reducing pain (oral sucrose). Breast milk has an analgesic effect similar to sucrose and can be used as a sensory gustatory stimulus in multisensory stimulation to reduce pain intensity in neonates.

Intervention: Three intervention groups were used: the sucrose group (30 infants) received $0.5 \mathrm{ml}$ of 24 percent sucrose 2 minutes before the vein puncture, the music group (30 infants) received $0.5 \mathrm{ml}$ of 24 percent sucrose 2 minutes before the vein puncture, and the control group ( 30 infants) received $0.5 \mathrm{ml}$ of 24 percent sucrose 2 minutes before the vein puncture. Braham's lullaby music at 40-50 dB was played through headphones for 10 minutes.

Sample Age : Baby with a gestational age of 32-35 weeks (as determined by an ultrasound 


\begin{tabular}{|c|c|}
\hline $\begin{array}{l}\text { (Author) } \\
\text { Country }\end{array}$ & Summary of Each Articles \\
\hline & $\begin{array}{l}\text { during the first trimester of pregnancy) and a birth weight of } 1500 \text { grams } \\
\text { Pain Megsurement: } \text { used PIPP }\end{array}$ \\
\hline & $\begin{array}{l}\text { Result: Pain scores during venipuncture were significantly lower in the sucrose and } \\
\text { combination groups than in the control group ( } \mathrm{p}=.003, \mathrm{p} .001 \text {, respectively) but not in the } \\
\text { music group. Thirty seconds after the venipuncture, pain scores in the three intervention } \\
\text { groups were significantly lower than in the control group ( } \mathrm{p} 001, \mathrm{p}=009 \text {, and } \mathrm{p} 001 \text {, } \\
\text { respectively, for sucrose, music, and combination group). }\end{array}$ \\
\hline & $\begin{array}{l}\text { Conclusion: Thirty seconds after the venipuncture, sucrose or a combination of sucrose and } \\
\text { music can relieve pain. To assess the analgesic effect of music on infants, it is } \\
\text { recommended that music be played for a longer period of time. }\end{array}$ \\
\hline
\end{tabular}

(Sen \& Manav, Intervention: The first group (32 infants) received kangaroo care beginning 15 minutes 2020) before blood collection, and the second group (32 infants) received $0.5 \mathrm{~mL}$ of oral sucrose Turki beginning 15 minutes before blood collection (24 percent ). The second group was given 2 minutes before the blood was drawn.

Sample Age : 64 infant, age of 0-28 days (gestations age between 32-37 weeks)

Pain Measurement: used PIPP

Result: In the kangaroo and sucrose groups, changes in PIPP values during stabbing were statistically significant ( $\mathrm{p} 0.001)$. Two minutes after stabbing, the PIPP value in the kangaroo group was lower than in the sucrose group (p 0.001). The difference in PIPP values during and after insertion was statistically significant $(\mathrm{p}=0.002)$ between the oral sucrose and kangaroo care groups.

Conclusion: The kangaroo treatment was more effective than oral sucrose in reducing pain during puncture.

\section{DISCUSSION}

Of the 11 articles chosen (see Table 1), 8 stated that sucrose could reduce pain in the invasive process in infants, while 3 stated that sucrose was ineffective in reducing pain in infants, either while the invasive process was ongoing or after it was completed (Cook et al., 2017; Gao et al., 2018; Gouin et al., 2018). The concentration of sucrose used to reduce pain in invasive procedures is $20 \%$ (Gao et al., 2018). Other articles stated that the concentration was between 24 and $25 \%$. For the administration procedure, the baby will be given sucrose 2 minutes before the invasive procedure, and pain measurements will be taken right when the needle is inserted or 30 seconds after the invasive procedure is completed. Sucrose dosage ranges from $0.5 \mathrm{~mL}$ to $5 \mathrm{~mL}$.

Sucrose is the scientific name for table sugar (sand). Sucrose is a disaccharide sugar made up of $50 \%$ glucose and 50\% fructose. Although it contains both glucose and fructose, sucrose is not as sweet as fructose but has a sweeter taste than glucose. Sucrose extracts from sugar cane or sugar beet are examples of sucrose that is commonly used in food (Kubala, 2018). Sucrose also serves as energy for the body, but it must be broken down into simpler forms, namely glucose and fructose. Sucrose, in addition to producing energy, aids in the metabolism of the body. Like energy, sucrose is broken down first by enzymes into glucose and fructose, which are then separated according to their respective metabolic pathways (Setiaji, 2020).

The PIPP (Premature Infaint Pain Profile) instrument was used in nine of the eleven articles, while the FLACC pain measurement instrument was used in the other two (Face, Legs, Activity, Cry, Contability pain scale). The PIPP is a pain measurement instrument for infants that is based on behavioral, physiological, and contextual factors such as furrowed brows, closed eyes such as when holding something, heart rate, oxygen saturation, gestational age, and behavioral status. The PPIP meter measured pain on a scale of 0 to 21. Mild scores with values (0-6), moderate scores with values (7-12), and worst pain scores with score (13-21) (Fitri et al., 2020). FLACC is a pain reduction score that is assessed from the face, feet, activity, crying, and pain scale, while other instruments that can measure pain in infants are FLACC. Because it is simple to implement in nursing care, pain measurement using the FLACC scale method is simple and relatively easy to use. Furthermore, because the FLACC scale can be used to measure pain in children with speech disorders and other limitations, it can be stated that pain measurement using the 
FLACC scale is required, particularly for newborn babies or babies who cannot speak (Willis et al., 2003) The pain range on the FLACC scale pain measurement method is as follows: light (0-3), medium (4-6), and heavy (7-10) (Hockenberry \& Wilson, 2011).

Several interventions other than sucrose have been shown in 11 studies to reduce pain in neonates undergoing infusion, venipuncture, or other procedures that require needle insertion in neonates. The intervention consists of a combination of sucrose and a pacifier (Gao et al., 2018), combination sucrose with music (Barandouzi et al., 2020; Shah et al., 2017). Other combination is kangaroo mother care (Sen \& Manav, 2020; Shukla et al., 2018), and breastfeeding (Collados-Gomez et al., 2018; Fitri et al., 2020)

To reduce pain in babies, use kangaroo care (skin to skin) for newborns before and after heel punctures, and give non-nutritive sucking, with sucrose solution, pacifiers, or breastfeeding for newborns for a few minutes before taking action (Kyle \& Carman, 2014) (Potter, P \& Perry, 2016). Music can also be used as a form of therapy to help babies cope with pain and stress (Gooding, 2010).

There are two types of pain relief therapy: pharmacological and non-pharmacological. Because of its short-term effect and high tolerance, non-pharmacological therapy is recommended for the treatment of mild pain (Zakiyah, 2015). Non-pharmacological treatment of patient pain problems is a nursing action that is safe, non-invasive, and inexpensive, and it can be performed independently (Tamsuri, 2015).

\section{CONCLUSION}

Oral sucrose is effective in reducing pain in premature infants when administered 2 minutes before invasive procedures (infusion and blood collection). Sucrose at a concentration of 20-25 percent is given in 0.5-5ml doses. Breastfeeding, kangaroo mother care (KMC), music, and pacifiers, in addition to sucrose, can be used to reduce pain. However, the pain measurement should be clear in infant and reducing the bias of result.

Pain measurements in infants cannot be used in adult pain measurements. This is because babies do not yet have verbal communication in language. As a result, the assessment of pain in infants should include an objective clinical response from the infant. Some effective pain measurements for infants include: Premature Infant Pain Profile (PIPP); Face, Legs, Activity, Cry and Consolability Pain Scale (FLACC); Neonatal Infant Pain Scale (NIPS); Premature Infant Pain Profile-Revised scale (PIPP-R); and Skin Conductance Algesimeter (SCA).

\section{REFERENCE}

Asadi-Noghabi, F., Tavassoli-Farahi, M., Yousefi, H., \& Sadeghi, T. (2014). Neonate pain management: what do nurses really know? Global Journal of Health Science, 6(5), 284-293. https://doi.org/10.5539/gjhs.v6n5p284

Barandouzi, Z. A., Keshavarz, M., Montazeri, A., Ashayeri, H., \& Rajaei, Z. (2020). Comparison of the analgesic e ff ect of oral sucrose and / or music in preterm neonates: A double-blind randomized clinical trial. Complementary Therapies in Medicine, 48(102271), 1-5. https://doi.org/10.1016/j.ctim.2019.102271

Beheshtipoor, N., Memarizadeh, A., Hashemi, F., Porarian, S., \& Rambod, M. (2014). No Title. The Effect of Kangaroo Care on Pain and Physiological Parameters in Preterm Infants on Heel-Stick Procedure: A Randomized Controlled Crossover Study, 2 (4), 157-168.

Collados-Gomez, L., Ferrera-Camacho, P., Fernandez-Serrano, E., Camacho-Vicente, V., Flores-Herrero, C., Garcia-Pozo, A., \& JimEnez-Garcia, R. (2018). Randomised crossover trial showed that using breast milk or sucrose provided the same analgesic effect in preterm infants of at least 28 weeks. Acta Paediatrica, 107, 436-441. https://doi.org/10.1111/apa.14151

Cook, L. M., Nichols-dada, J., Damani, S., Lawrence, V., Layson, S., Mitchell, D., Muhammad, S., Samaniego-yamin, L., Talley, J. W., VanNatta, B., Higgins, M., \& Cooley, K. (2017). Randomized clinical trial of $24 \%$ oral sucrose to decrease pain associated with peripheral intravenous catheter insertion in preterm and term newborns. Advances in Neonatal Care, 17(1), 3-11. https://doi.org/10.1097/ANC.0000000000000326

Fitri, S. Y. R., Lusmilasari, L., Juffrie, M., \& Bellieni, C. V. (2020). Modified sensory stimulation using breastmilk for reducing pain intensity in neonates in indonesia: a randomized controlled trial. Journal of Pediatric Nursing, 53, e199-e203. https://doi.org/10.1016/j.pedn.2020.04.004 
Gao, H., Li, M., Gao, H., Xu, G., Li, F., Zhou, J., Zou, Y., \& Jiang, H. (2018). Effect of non-nutritive sucking and sucrose alone and in combination for repeated procedural pain in preterm infants: A randomized controlled trial. International Journal of Nursing Studies, 83(August 2017), 25-33. https://doi.org/10.1016/j.ijnurstu.2018.04.006

Gooding, L. F. (2010). Using music therapy protocols in the treatment of premature infants: An introduction to current practices. 37, 211-214.

Gouin, S., Gaucher, N., Lebel, D., \& Desjardins, M. P. (2018). A randomized double-blind trial comparing the effect on pain of an oral sucrose solution vs. Placebo in children 1 to 3 months old undergoing simple venipuncture. The Journal of Emergency Medicine, 54(1), 33-39. https://doi.org/10.1016/j.jemermed.2017.08.015

Hastuti, W., Pujiwati, S., \& Apriliyanti, R. (2021). Pemberian air susu ibu (ASI) dan dextrose $5 \%$ untuk mengurangi nyeri pemasangan infus pada neonatus (breast milk and dextrose $5 \%$ to reduce the pain of infusion in neonates). Jurnal Ilmu Keperawatan Maternitas, 3(1).

Hatfield, L. A., Gusic, M. E., Dyer, A.-M., \& Polomano, R. C. (2008). Analgesic properties of oral sucrose during routine immunizations at 2 and 4 months of age. Pediatrics. https://doi.org/10.1542/peds.20063719 .

Hockenberry, M. J., \& Wilson, D. (2011). Wong's Clinical Manual of Pediatric Nursing.

Kemenkes RI. (2018). Hasil Riset Kesehatan Dasar Tahun 2018. Kementrian Kesehatan RI, 53(9), 16891699.

Kementerian Pemberdayaan Perempuan dan Perlindungan Anak dan Badan Pusat Statistik. (2019). Profil Anak Indonesia Tahun 2019. Kementerian Pemerdayaan Perempuan Dan Perlindngan Anak (KPPPA), 378.

Kristoffersen, L., Malahleha, M., Duze, Z., Tegnander, E., Kapongo, N., Stoen, R., Follestad, T., Eik-Nes, S. H., \& Bergseng, H. (2018). Randomised controlled trial showed that neonates received better pain relief from a higher dose of sucrose during venepuncture. Acta Paediatrica, 107, 2071-2078. https://doi.org/10.1111/apa.14567

Kubala, J. (2018). Sucrose Is Made up of Glucose and Fructose. 3 Juni. https://www.healthline.com/nutrition/sucrose-glucose-fructose\#what-are-they?

Kyle, T., \& Carman, S. (2014). Buku Praktik Keperawatan Pediatri. ECG.

Liaw, J.-J., Yang, L., Lee, C.-M., Fan, H.-C., Chang, Y.-C., \& Cheng, L.-P. (2013). Effects of combined use of non-nutritive sucking, oral sucrose, and facilitated tucking on infant behavioural states across heelstick procedures: a prospective, randomised controlled trial. https://doi.org/10.1016/j.ijnurstu.2012.08.021.

Passariello, A., Montaldo, P., Palma, M., Cirillo, M., Guida, C. Di, Esposito, S., Caruso, M., Pugliese, M., \& Giliberti, P. (2019). Neonatal painful stimuli: skin conductance algesimeter index to measure efficacy $24 \%$ of sucrose oral solution. The Journal of Maternal-Fetal \& Neonatal Medicine, O(0), 1-6. https://doi.org/10.1080/14767058.2019.1580690

Potter, P, A., \& Perry, A. (2016). Fundamental Keperawatan, Konsep, Klinis dan Praktik. Penerbit Buku Kedokteran EGC.

Rustina, Y. (2015). Bayi prematur: Perspektif keperawatan. CV Sagung Seto.

Sen, E., \& Manav, G. (2020). Effect of kangaroo care and oral sucrose on pain in premature infants: A randomized controlled trial. Pain Management Nursing, 21(6), 556-564. https://doi.org/10.1016/j.pmn.2020.05.003

Setiaji, R. B. R. (2020). Sama-Sama Gula, Tapi Apa Bedanya Sukrosa, Glukosa, Fruktosa? 18 Desember. https://hellosehat.com/nutrisi/fakta-gizi/beda-jenis-gula-sukrosa-glukosa-fruktosa/

Shah, S. R., Kadage, S., \& Sinn, J. (2017). Trial of music, sucrose, and combination therapy for pain relief during heel prick procedures in neonates. The Journal of Pediatrics, 190, 153-158.e2. https://doi.org/10.1016/j.jpeds.2017.08.003

Shukla, V., Chapla, A., Uperiya, J., Nimbalkar, A., Phatak, A., \& Nimbalkar, S. (2018). Sucrose vs. skin to skin care for preterm neonatal pain control - a randomized control trial. Journal of Perinatology, June 2017, 1-5. https://doi.org/10.1038/s41372-018-0193-9

Tamsuri, A. (2015). Konsep dan Penatalaksanaan Nyeri. Penerbit Buku Kedokteran EGC.

Widayati, F., Arief, Y. S., Pradanie, R., Studi, P., Ners, P., Keperawatan, F., \& Airlangga, U. (1996). 
Peningkatan patensi pemasangan iv line pada neonatus dengan penggunaan elastic bandage. 031.

Willis, M. H. W., Merkel, S. I., Voepel-Lewis, T., \& Malviya, S. (2003). FLACC behavior pain assessment scale: Acomparrison with the child's selfreport.

World Health Organization. (2018). Preterm Birth. 19 Februari. https://www.who.int/news-room/factsheets/detail/preterm-birth

World Health Organization. (2019). Low BirthWeight. Mei. https://data.unicef.org/topic/nutrition/lowbirthweight/

Wulandari, R. (2011). Peran Perawat Anak terhadap Prinsip Perawatan Atraumatik Pada Anak. Peran Perawat Anak Terhadap Prinsip Perawatan Atraumatik Pada Anak, 8.

Zakiyah, A. (2015). Nyeri Konsep dan Penatalaksanaan Dalam Praktik Keperawatan Berbasis Bukti. Salemba Medika. 